\title{
Combining art activities and nature in pre-school education ${ }^{*}$
}

\section{Okul öncesi eğitimde sanat etkinlikleri ve doğayı birleştirmek}

\author{
Zeynep Temiz ${ }^{1}$, Güliz Karaarslan Semiz ${ }^{2}$
}

\section{Article History}

Received : 28 August 2018

Revised : 13 September 2018

Accepted : 20 September 2018

Online : 21 September 2018

Article Type

Original Article

\begin{abstract}
The purpose of this study was to integrate nature and natural materials in art activities in pre-school education setting. Eight pre-service early childhood teachers taking practicum course participated in this study. Pre-service teachers were encouraged to use nature and natural materials in art activities through ten weeks period. Qualitative data consisted of art activities conducted with natural materials in the practicum course and interviews conducted with pre-service teachers before and after they applied their activities. Findings of the study revealed that pre-service teachers used unusual and engaging material compared to conventional stationary materials generally used in art activities. Pre-service teachers' art materials included stones, leaves, soil, sand, bones, fruits, animal products and parts but not limited to those materials. Pre-service teachers used these materials in their art activities in two different ways. First, they used these materials as substitutes of stationery materials. For instance, they filled the bird picture with stones and leaves instead of filling with colourful papers, beads and silver. Second use of natural materials fit better to aim of this study since pre-service teachers lead children to create authentic art products with natural materials that they provide to them. Moreover, throughout the course pre-service teachers' self-confidence to apply nature based art activities developed.
\end{abstract}

Keywords: Art activities; nature-based teaching; environmental education; nature; natural materials

Öz: Bu çalışmanın amacı okul öncesi eğitimde doğayı ve doğal malzemeleri sanat etkinlikleriyle birleştirmektir. Çalışmaya okul deneyimi dersini alan sekiz öğretmen adayı katılmıştır. Öğretmen adayları on hafta boyunca doğa ve doğal malzemeleri sanat etkinliklerinde kullanmaları için teşvik edilmişlerdir. Çalışmanın nitel verileri okul deneyimi dersinde doğal malzemelerle uygulanan sanat etkinlikleri ve çalışmaya katılmadan önce ve sonra yapılan görüşmelerden oluşmaktadır. Çalışmanın verilerine göre öğretmen adaylarının sanat etkinliklerinde çoğunlukla kullanılan kırtasiye malzemelerine yerine daha az kullanılan ve daha ilginç malzemeler kullandıkların ortaya koymuştur. Öğretmen adaylarının kullandıkları materyaller taş, yaprak, toprak, kum, kemik, meyve, hayvanlara ait olan parçalar ve ürünleri içermekle birlikte bunlarla sınırlı değildir. Öğretmen adayları bu malzemeleri etkinliklerinde iki farklı şekilde kullanmışlardır. İlk olarak doğal malzemeleri kırtasiye malzemelerinin yerine kullanmışlardır. Örneğin, bir kuş resmini renkli kağıtlar, sim ve boncuk yerine taş ve yapraklarla doldurmuşlardır. İkinci kullanılış şekli bu çalışmanın amacına daha çok uymaktadır çünkü öğretmen adayları çocukları doğal malzemelerle özgün ürünler yaratmaya yönlendirmişlerdir. Ayrıca ders süresince öğretmen adaylarının doğa temelli sanat etkinliklerinin uygulanmasına yönelik kendilerine güvenleri artmıştır.

Anahtar Kelimeler: Sanat etkinlikleri; doğa-temelli eğitim; çevre eğitimi; doğa; doğal malzemeler

\footnotetext{
${ }^{*}$ This study was presented at the 8th EYFOR Congress, Ankara, Turkey. Corresponding Author: Zeynep Temiz

${ }^{1}$ Karamanoğlu Mehmet Bey Üniversitesi, Eğitim Fakültesi, Temel Eğitim Bölümü, ztemiz@kmu.edu.tr, ORCID: 0000-0002-4436-9737 2 Ağrı İbrahim Çeçen Üniversitesi, Eğitim Fakülte, Matematik ve Fen Bilimleri Eğitimi Bölümü, gkaraarslan@agri.edu.tr, ORCID: 00000003-2717-9998
} 


\section{INTRODUCTION}

Children are born as a natural explorer and wonderer. They start to learn, explore and interact with everything in their environment from the beginning. Children should be grown in an environment where they could wonder, learn and explore all living and non-living things (Pramling \& Samuelson, 2011). Therefore, educational spaces are important for children's development. Especially natural outdoor settings provide endless opportunities for learning in all curricular domains (Ernst, 2014). As Commenius claimed while learning a subject children should build a connection with a stone, a plant or an animal. Nature is the best teacher and they could learn many things from nature (Berberoğlu \& Uygun, 2013; Kanad, 1948). Today because of the urbanization and losing of natural spaces children spend less time outdoors and they have lack of experiences in nature (Louv, 2008). Moreover, many parents are over protective and they are afraid of risks of outdoor play (Silverman \& Corneau, 2007). Children who spend less time outdoors are grown up as being unaware of natural environment in their surrounding (White, 2004). According to Louv (2008) children better recognize characters of pokemon rather than natural species in their environment. The author also states that if people don't know name of the species, they don't value them and not willing to protect them. Therefore, children should be taught how to observe, feel and explore natural environment (Louv, 2008; Sobel, 2014). Furthermore, spending time in natural environment in the childhood develops positive attitudes toward environment, a strong connection to nature and develop a strong sense of place (Cheng \& Monroe, 2012; Gerrish, 2014). Therefore, there is a need to teach children to be aware of their environment, to love, wonder and explore nature (Gill, 2014). For this reason, early childhood teachers are major factors for planning and implementing nature-based activities (McClintic \& Petty, 2015). However, early childhood teachers may not be aware of learning opportunities and experiences in natural environment (Ernst, 2014).

Frobel who is accepted as a founder of kindergartens emphasized extensive use of outdoor in children's education. He stated that interaction with nature help young children to construct meaningful learning as children associate abstract concepts with the real one (Wardle, 2009). Today because of many reasons like cultural, risk factors, expectation of families, early childhood educators hesitate to take children outside. Both children and early childhood preservice teachers spend lack of time in nature (Ernst \& Tornabene, 2012). Therefore, there is a need to prepare early childhood teachers to effectively use natural spaces and increase children's experiences in nature (Ernst \& Tornabene, 2012). Early childhood pre-service 
teachers should be encouraged to use natural outdoor settings in their teaching practices. In this context, this study was conducted for developing early childhood pre-service teachers' experiences related to nature based teaching while conducting art activities.

A new paradigm of education is built on a more dynamic, creative, and realistic view of what kind of quality new world requires from coming generation. This new paradigm portends the questions of how young people learn and how they make sense of their experiences. In this sense art education could be an alternative way of teaching as it includes thinking, processing and creativity (Marshall, 2014).Unfortunately, in Turkey art activities are generally teacherdirected and teachers relied heavily on cutting, pasting, folding, dying activities with stationery materials. These activities are highly structured and do not offer children freedom to express their creativity (Gol-Guven, 2009; Temiz, 2017). Art activities should be meaningful for children in order to make them responding, engaging and learning in the art activities that teacher set for them. Making art is rooted intimately in the personal process in which an individual makes life meaningful by reflecting their uniqueness to society. A single art product is originated from intention, endeavour and investment; that is, people have reason to pick up to brush to paint, stay committed and make something when there is the option to walk away. Thus,, people have innate power to make art (Malin, 2013). Conducting art activities with natural materials might enable teachers to leave stereotype art activities in which teacher offered a model and want children to produce similar one. Natural materials might let teachers to make more free, creative and dynamic activities. Art activities have potential to provide an opportunity to incorporate the play-based curriculum into traditional school day. Besides, nature and natural materials could provide inspiration for experiential learning, adventure, and collaboration that can be easily incorporated into the art activities (Bradshaw, 2018). Through the art activities children can explore nature. That is to say, they can learn diversity of natural environment by touching a tree bark, stones, leaves, flowers and soil. Furthermore, they can see different colours of plants and animals with regard to nature based art activities (Plevyak \& Mayfield, 2010).

In today's industrial world, we are breaking our bonds with nature and we are separated from it day by day. In particular, children spend less time in nature and they are losing their sense of connection with nature and culture (Louv, 2008). Therefore, we need to find a way to transfer our natural values to the coming generations. Early childhood education could be a good start 
and using nature and natural material in art activities could be prosperous alternative. At this point this study seeks to answer following research questions:

- How pre-service pre-school education teachers' perceptions and self-confidence change while integrating nature and natural materials into art activities?

- How pre-service pre-school education teachers integrate nature and natural materials into art activities?

\section{METHOD}

\section{Context and participants}

The city of Van where this study was implemented is located in the eastern Anatolia. Van is one of the big cities of the eastern region of Turkey and it is surrounded with the biggest lake of the country. The socio-economic state of the city is low compared to big cities in the western Anatolia. The population of the city has increased because of the migrating people from the border cities. Although the city has natural and aesthetic values, there is an irregular urbanization and therefore, there is lack of natural spaces in the city center (Ministry of City and Environment, 2014). There is a need to use natural environment in the city of Van to develop children's connection to nature. Therefore, this study was conducted in the practicum course in the department of Early Childhood Education in the 2016-2017 academic year. Eight senior pre-service early childhood teachers (five female, three male) taking practicum course attended in this study. Pre-service teachers were in their last year in early childhood teacher education program and they are required to prepare daily and annual plans based on the objectives and goals stressed in the MONE curriculum, and then carry out classroom activities according to those plans (MoNE, 2013). The participants were monitored throughout ten weeks.

Practicum course consisted of both practice and theoretical parts. In theoretical courses preservice teachers were provided examples of activities that integrate nature and natural materials in early education setting. Then pre-service teachers prepared lesson plans to apply their naturebased activities in the practicum school with children for ten weeks. The practicum school has a rounded garden but does not offer children so many opportunities related to nature. With the help of this study, the school garden was used more effectively by children. Eight pre-service teachers conducted nature based art activities with four and five years old children in the practicum school. 


\section{Data Collection and Implementation}

A basic qualitative research study (Merriam, 2009) was conducted by collecting data through a series of two semi-structured interviews and pre-service teachers' lesson plans. Pre-service teachers were interviewed before and after implementing nature based activities in the practicum course. Interview questions were prepared by the researchers and one expert examined interview questions for providing validity (Table-1).

\section{Table 1. Sample interview questions}

1. Have you ever prepared nature related activities before?

2. Have you ever observed nature related activities in practicum schools? How was the children's participation?

3. What is the benefit of nature related activities for children?

4. How parents react to nature related activities?

Lesson plans prepared by the participants were also examined. These lesson plans were integrated into research methodology in order to document pre-service early childhood education teacher's comprehensive picture of the lived experiences of applying nature based art activities. Analysis of lesson plans were used to provide triangulation of the qualitative data.

\section{Data Analysis}

While analysing interviews themes and categories were determined based on the data and relevant literature (eg., Ernst, 2012; 2014). Data were read several times and pre-service teachers' excerpts were selected to support codes and categories (Creswell, 2007). Pre-service teachers' lesson plans were analysed through content analysis technique as it generally concentrates on written content of communication (Frankel \& Wallen, 2003). Coding categories were determined based on the previous studies. As such, deductive analysis was conducted to determine the themes and categories that pre-service teachers addressed in their field practice activities. For ensuring inter-coder reliability two researchers coded data independently and 92\% agreement was achieved. Moreover, to provide confidentiality issue, the participants signed a consent form prior to participation and their names were not used in the study instead, they were presented as $\mathrm{P}-1$ to $\mathrm{P}-8$. 


\section{RESULTS}

\section{Interviews}

Researchers conducted two interviews with pre-service teachers before they implement their nature based art activities and after they completed their activities. Before attending in practicum course, pre-service teachers were asked their past experiences related to nature based teaching. Table-2 presents themes and categories based on the data analysis

Table 2. Themes and categories based on the data analysis

\begin{tabular}{ll}
\hline Themes & Categories \\
\hline & $\begin{array}{l}\text { Category-1: Childhood experiences related to } \\
\text { nature based activities }\end{array}$ \\
$\begin{array}{l}\text { Theme-1: Pre-service teachers' background } \\
\text { experiences related to nature based art activities }\end{array}$ & $\begin{array}{l}\text { Category-2: Pre-service teachers' lack of } \\
\text { experiences regarding nature based art activities }\end{array}$ \\
\cline { 2 - 3 } $\begin{array}{l}\text { Theme-2: Pre-service teachers' perceptions and } \\
\text { self-confidence regarding nature based activities }\end{array}$ & $\begin{array}{l}\text { Category-1: Pre-service teachers' perceptions } \\
\text { regarding nature based art activities }\end{array}$ \\
& $\begin{array}{l}\text { Category-2: Pre-service teachers' self-confidence } \\
\text { regarding nature based art activities }\end{array}$ \\
\hline
\end{tabular}

\section{Theme-1: Pre-service teachers' background experiences related to nature based art activities}

Category-1: Childhood experiences related to nature based activities

All of the participants described that they had several experiences with nature in their childhood as they were grown up in countryside. They stated that they tried to make some art activities in nature. P6 exemplified their art activities like playing in nature and people's possible reactions to play in nature:

'I made pottery with mud with my friends in our garden. Then, let them dry under the sun. I think it was kind an art activity. We could make it with children but parents and school principal would prefer to make this kind of activities as children's clothes may get dirty.'

\section{Category-2: Pre-service teachers' lack of experiences regarding nature based art activities}

Participants stated that natural materials and nature should be integrated in art activities. Yet, they mentioned that they witnessed limited use of natural materials both in their courses in the faculty and practicum schools. Therefore, they had lack of experiences about how to conduct nature based art activities. For instance, P3 emphasized importance of nature based activities and she complained about lack of these activities in their courses and practicum schools as they 
could not find any opportunity to observe and apply nature related activities along with their education.

'I have been always tending to conduct nature based activities but we did not learn much about it in our courses. It has been emphasized that children learn best in nature. They become happier and heathier in nature. Spending time in nature supports their development. I have already known that but I do not know how to integrate nature in to my teaching practice. I have just seen that some of the teachers make leaf prints or they colour stones. I need more than that.'

Theme-2: Pre-service teachers' perceptions and self-confidence regarding nature based art activities

Before involving in this study pre-service teachers have already been aware of the crucial role of nature-based activities in early childhood settings, yet they have lack of knowledge and experiences related to practicing nature-based activities. As such, they pointed out that they need educational support to develop their skills and experiences for nature-based teaching. After researching, discussing, preparing and implementing of ten weeks of nature based art activities, pre-service teachers' perceptions and self-confidence increased to conduct naturebased activities. All of the participants stated that they felt more motivated and confident to implement nature-based activities in early childhood. Example quotations from the second interviews are presented below:

'At first I have some concerns that children might not like to work with natural material as you know all art activities are conducted with colorful papers, silver, paint and beans. Children like these kind of stuff. Then, I saw their reaction. Children got used see natural materials in their environment but they are not exposed them as educational materials. When I introduce natural materials for educational purpose in class children's interest increased.'(P6)

'While implementing art activities with natural materials I realized that my knowledge and interest to nature increased as well. I begin to appreciate natural beauty more. It is a misunderstanding that natural beauty is just flowers, trees and magnificent waterfalls. I believe that dried plants, animal products or parts, tree's bark would be very aesthetic if we could bring them in a proper harmony.' 


\section{Lesson Plans}

Natural materials and outdoor activities were designed to help children to connect with natural world more deeply. Activities prepared by pre-service teachers provided opportunity children to see natural materials and natural world around them from multiple perspectives. Children observed, touched, smelled, listened different shapes, colours, textures, smells, sounds and patterns. In total 37 activities were examined during the analysis of lesson plans and these activities were found to be directly related with natural materials. Pre-service teachers used these materials in art activities in two different ways. First, they used these materials as substitutes of stationery materials. For instance, they filled the bird picture with stones and leaves instead of filling with colourful papers, beads and silver. Second use of natural materials fit better to aim of this study since pre-service teachers lead children to create authentic art products with natural materials that they provide to them. Therefore, two categories were emerged from the lesson plans analysis: 1. Traditional use of natural materials in art activities 2. Open ended and creative use of natural materials in art activities.

Table 3 presents different natural materials and number of them that pre-service teachers used in their activities.

Table 3. Natural materials used in art activities.

\begin{tabular}{lc}
\hline Natural materials & Number of use \\
\hline Stones & 8 \\
\hline Leaf, tree branches, and tree products & 7 \\
Fruits, Fruit's seeds, stones and peels & 7 \\
\hline Soil, sand, coal & 6 \\
Animal products & 6 \\
Water & 3 \\
\hline
\end{tabular}

\section{Traditional use of natural materials in art activities}

21 activities were prepared to use natural material as substitute of stationery materials. In those activities pre-service teachers conducted teacher directed art activities by replacing the material with natural one. P4 conducted hand print activity with mud in the school garden. She prepared a bucket of mud and bucket of water and delivered paper to children. Children first reach into mud bucket and print their hand on paper. Then they cleaned their hands in the bucket filled with water. This activity is a good example of how art activities are easy and cheap to conduct 
with natural materials. Teachers generally need acrylic paint or watercolour to implement the same activity.

It is one of the most common art activity in pre-school classes is that filling a picture with different materials. In general children are provided with an animal, human or flower picture then they fill the picture by either teacher's instruction or by their own decision. There are six examples of this activity in this study. P8 let children go to school garden and then she allows them to collect stones, leaves, tree branches. Then pre-service teacher asked children to fill their picture with the materials that they collected from garden. Although it is an example of a stereotype art activity children go outside and they collect and decide their art materials on their own. In this process children observe, think, make decision, take initiative and actively engage. Most importantly children get in touch with natural materials and used them in purpose. As it is seen in Figure 1 children made a college with natural materials.
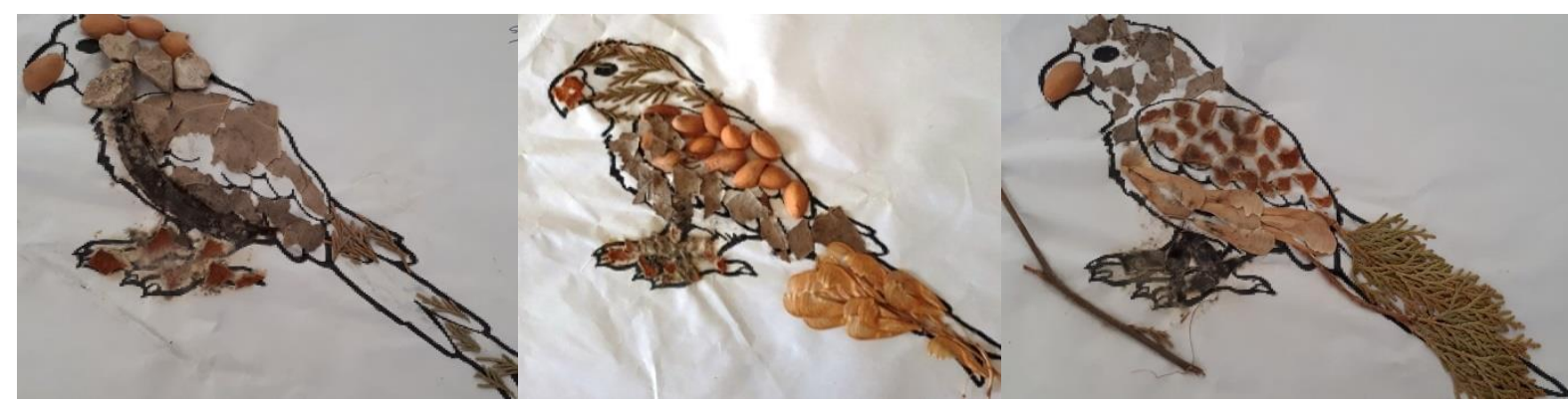

Figure 1. Same art product with different natural materials

P7 brought pine cones to class and asked children "Do you know what it is? Have you seen this before? Where can we find it? What it is resembled"? After listening children's answers he explained that they will make an owl with pine cone. He showed a model owl and delivered pine cones and other materials to children. Each child made their owl with pine cones. Figure 2 exemplifies the children owls. 


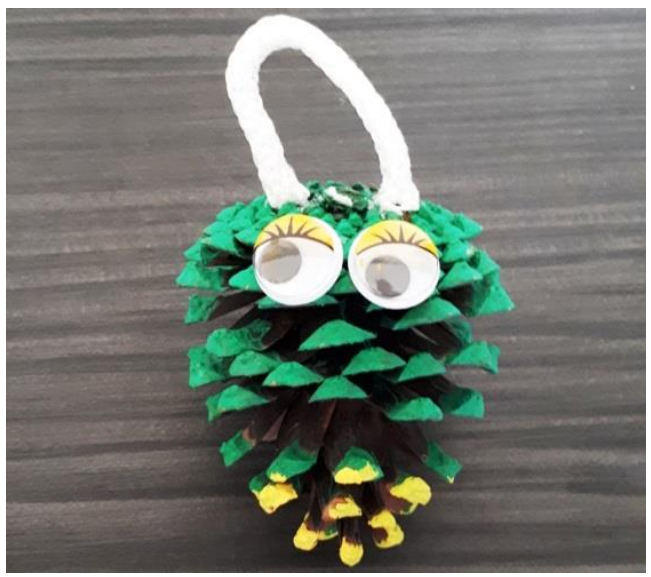

Figure 2. Traditional use of natural materials

\section{Open ended and creative use of natural materials in art activities}

Researchers guided pre-service teachers to use nature and natural materials in their teaching practices and roughly half of the participants conducted open-ended creative activities with natural materials. One of the participants brought a bucket of chicken bones into class and children created different shapes on the ground of school garden as seen in Figure 3. P6 stated that I made this activity with bones at the beginning of the semester and children asked me about bones throughout the semester. Bones really took their attention'.

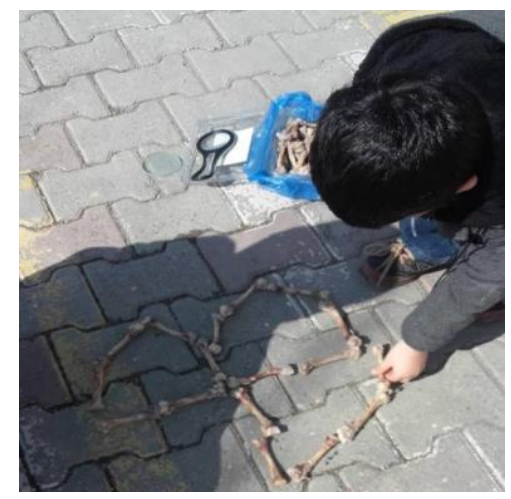

Figure 3. An example of creative art activity

Eating sunflower seeds is a fun activity in Turkish culture but, it is actually forbidden to eat in class because the class might get dirty. P1 combined play and art activity together. She first delivered sunflower seeds to each child. Children made a contest to eat sunflower seeds, then they created their authentic art products with sunflower seeds' peel on the floor not on the A4 paper. Figure 4 presents the art product of children with sunflower seeds. 


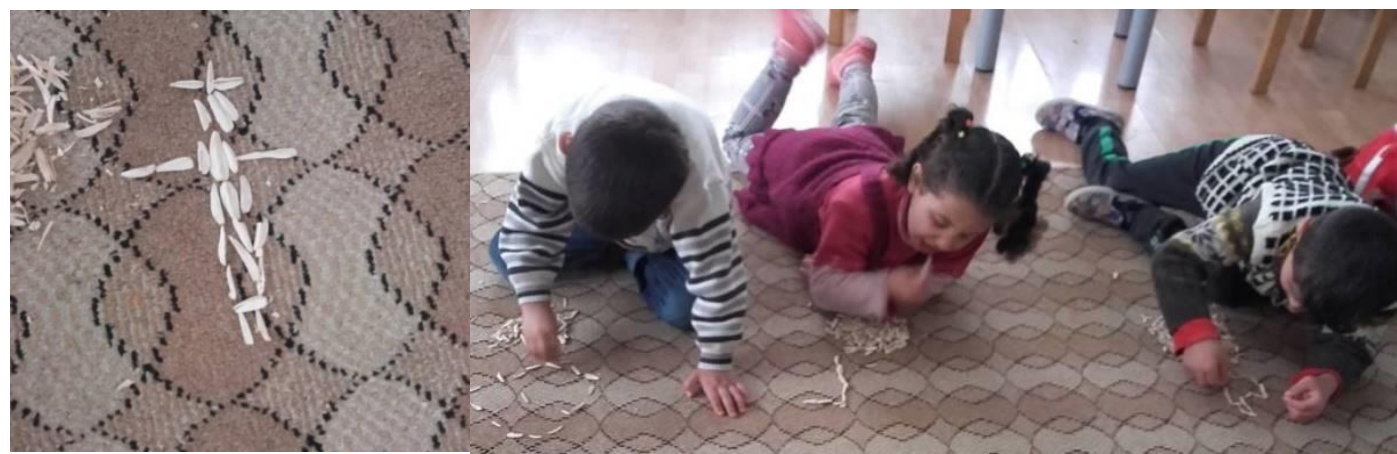

Figure 4. Another example of creative art activity

Painting is an indispensable parts of art activities in pre-school setting. Three pre-service teachers conducted stone painting activities with children. P3 delivered all children a bag and want them to collect stones from the garden. Children went outside and collected stones and then they washed stones and let them to dry under the sun. After that children painted their stones. P3 expressed that 'Children exhibit more possession to stone art product than regular art product. It might have originated from involving in finding and choosing their stone. When they are offered an A4 paper they do not exhibit the same possession.'

Another activity was conducted by P6 again. Pre-service teacher said children 'I will have a surprise to you. Please do not throw your olive stones'. Children gave their olive stone to preservice teacher after breakfast. Teacher collected them in a bowl and disinfected them. Then children went outside and made authentic pictures with olive stones as it is seen in Figure 5. P6 explained how children were eager to conduct this activity:

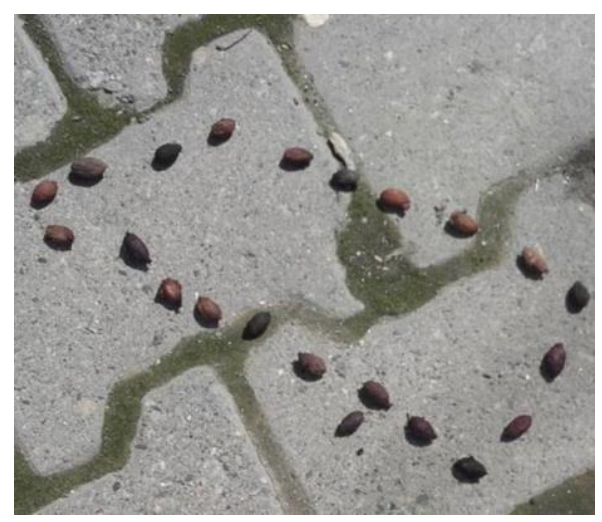

Figure 5. An example of creative art activity

'We have been learning for four years in our courses that children learn best when their curiosity is triggered. I am taking children attention by saying that I have a 
surprise to you. Even the olive stone is enough to make them curious. Class teacher said children sometimes left their olive in their plate but when I was doing this activity they ate all of the olives.' (P-6)

\section{DISCUSSION and CONCLUSION}

Today's world is experiencing consumption era. People want to replace their functional goods with the latest release. In this consumption oriented society people are directed to buy several things that they actually do not need (Baudrillard, 2016). In this study we try to show children that things they do not need could be useful for many purpose like bones, fruit stones, seeds and peels. Using waste materials in art activities and turning them to an aesthetic art product would be useful to teach children to value everything in nature.

White (2004) classified natural materials that young children would use in their learning environment as; water, plants, animals, sand, variety of texture, wind, light, sound, weather, natural places, different levels and nooks, structures, equipment and materials that can be changed. Similar to White's (2004) suggestions pre-service teachers used water, sand, stones, bonds, seeds, leaves in their nature based teaching. In this study children get a chance to interact with materials that they unlikely to encounter in class. Those natural materials are not expensive or difficult to find. Actually, those materials are free in nature and easily accessible for teachers. In rural parts of Turkey teachers suffer from material shortage therefore, conducting activities with easily accessible natural materials would be a remedy for their problems (Akdağ, 2014).

Pre-service teachers pointed out that both children's and their own wonder and interest to nature increased while preparing and implementing art activities with natural materials. They further indicated that applying art activities with natural materials helped them to discover and increase their potential of creativity. At the beginning of practice teaching course, pre-service teachers had lack of experiences for creating nature based art activities however, through the course they developed their skills and their self-confidence increased to apply nature based art activities. Furthermore, while participating in this activity pre-service teachers realized that children could not engage in activities in natural materials and natural environment in regular basis. They all declared that they will create several opportunities for children to interact with nature more when they become teacher. 
Using natural materials enable teachers to combine art and other activities together while using natural materials. For instance, children used an orange peel to fill the parrot's feet and as time passed orange peel got mouldy which would never happen in stationery materials. Teacher can hang children's art product on wall and then they can discuss how colour and shape changed in time. Children could observe their product and compare the result with their initial estimate that how leafs get dried, shrink and branches fell off from the paper. In this way children could discuss scientific concepts on their art product. Considering the fact that one of the way to improve children's creativity is to engage them in an activity in which children required to use conventional material for the new and unusual situations (Daniels \& Peters, 2013). Before making authentic art product with sunflower seeds they are just a waste that should be thrown to trash. Using natural materials enable children to observe how waste materials turn into aesthetic beauty. Findings of this study could function to increase use of nature and natural materials in pre-school setting. At the beginning of school year parents have to buy a list of stationery materials so that their children can make aimless art product with them. Nature related activities could also lessen parents' burden to buy all those stationery materials.

\section{REFERENCES}

Akdağ, Z. (2014). Beginning Early Childhood Education Teachers' Struggles in Remote Areas. International Journal of Educational Researchers, 5(3), 1-13.

Baudrillard, J. (2016). The consumer society: Myths and structures. Sage.

Bradshaw, M. (2018). Natural Connections: Forest Schools, Art Education, and Playful Practices. Art Education, 71(4), 30-35.

Berberoglu, E. O., \& Uygun, S. (2013). Sinif disi egitimin dunyadaki ve Turkiye'deki gelisiminin incelenmesi. Mersin Universitesi Egitim Fakultesi Dergisi, 9(2), 32-42.

Cheng, J. C. H., \& Monroe, M. C. (2012). Connection to nature: Children's affective attitude toward nature. Environment and Behavior, 44(1), 31-49.

Cresswell, J. W. (2007). Qualitative inquiry and research design: Choosing among five traditions (2nd ed.). Thousand Oaks, CA: Sage.

Daniels, S., \& Peters, D. B. (2013). Raising creative kids. Great Potential Press.

Ernst, J., \& Tornabene, L. (2012). Preservice early childhood educators' perceptions of outdoor settings as learning environments. Environmental Education Research, 18(5), 643-664.

Ernst, J. (2014). Early childhood educators' use of natural outdoor settings as learning environments: an exploratory study of beliefs, practices, and barriers. Environmental 
Education Research, 20(6), 735-752.

Frankel, J. R., \& Wallen, N. E. (2003). How to design and evaluate in education. New York: McGraw-Hill Higher Education

Gerrish, M.K. (2014). An examination of teachers' lived experiences while working at naturebased preschool programs. (Unpublished doctoral dissertation).Walden University, USA

Gill, T. (2014). The benefits of children's engagement with nature: A systematic literature review. Children Youth and Environments, 24(2), 10-34.

Gol-Guven, M. (2009). Evaluation of the quality of early childhood classrooms in Turkey. Early Child Development and Care, 179(4), 437-451.

Louv, R. (2008). Last child in the woods: Saving our children from nature-deficit disorder. Algonquin books.

Marshall, J. (2014). Transdisciplinarity and art integration: Toward a new understanding of artbased learning across the curriculum. Studies in Art Education, 55(2), 104-127.

McClintic, S., \& Petty, K. (2015). Exploring early childhood teachers' beliefs and practices about preschool outdoor play: A qualitative study. Journal of early childhood teacher education, 36(1), 24-43.

Merriam, S. B. (2009). Qualitative research. A guide to design and implementation. San Francisco: Jossey-Bass Publishers.

Ministry of National Education (2013). Early childhood education curriculum. Retrieved from http://tegm.meb.gov.tr/dosya/okuloncesi/ooproram.pdf

Plevyak, L., \& Mayfield, A. (2010). Environmental education within early childhood. In Bodzin, A., Klein, B. S., \& Weaver, S. (Eds.). The Inclusion of Environmental Education in Science Teacher Education (pp. 51-64). Springer, Dordrecht.

Turkish Ministry of Environment and City (2014). Retrieved from http://www.csb.gov.tr/db/ced/editordosya/VAN\%202014\%20(1).pdf

Pramling Samuelsson, I. P. (2011). Why we should begin early with ESD: The role of early childhood education. International Journal of Early Childhood, 43(2), 103.

Silverman, J., \& Corneau, N. (2017). From nature deficit to outdoor exploration: curriculum for sustainability in Vermont's public schools. Journal of Adventure Education and Outdoor Learning, 17(3), 258-273.

Sobel, D. (2014). Ekofobiyi aşmak: Doğa eğitiminde kalbin yeri (1. bask1). I. Urkun Kelso, Cev.). Ístanbul: Yeni İnsan Yaylnevi.

Temiz, Z. (2017). Which one is more beautiful? Creative arts versus stereotyped art activities. Journal of Inquiry Based Activities, 7(2), 51-61. 
Wardle, F. (2009). Approaches to early childhood and elementary education. New York: Nova Science Publishers.

White, R. (2004). Young children's relationship with nature: Its importance to children's development \& the earth's future. White Hutchinson Leisure \& Learning Group, 1-9. The Coalition for Education in the Outdoors, Cortland, New York. 